\title{
Analysing a Whole CLIL School: Students' Attitudes, Motivation, and Receptive Vocabulary Outcomes
}

Mario ARRIBAS*

\begin{abstract}
CLIL keeps on gaining ground in the European educational context, one clear example is Spain, where the number of schools adopting this methodology has kept growing exponentially in recent years. The present study has a dual perspective looking at the motivation of students towards English and CLIL and showing students' receptive vocabulary outcomes. All students $(n=403)$ enrolled in secondary education in a bilingual school fulfilled a questionnaire and completed two receptive vocabulary level tests (VLT $2 \mathrm{k}$ and $3 \mathrm{k}$ bands). The findings of the study report on all learners' opinions and it also correlates vocabulary outcomes from students of the last year of compulsory education (16 years old) with their motivation towards English. Once we analysed the questionnaire and the $2 \mathrm{k}$ and $3 \mathrm{k}$ versions of the VLT, we concluded that the CLIL group scored higher in receptive vocabulary tests due to their higher motivation, albeit differences were not found statistically significant (Kolmogorov-Smirnov-Lilliefors, Shapiro-Wilk, and Mann-Whitney tests). We attribute this lack of statistical significance to the irregular CLIL implementation in the school and the short experience of the school with this methodology.
\end{abstract}

Key words: CLIL; receptive vocabulary; attitudes; motivation.

* orcid.org/oooo-0002-5082-2411. Universidad de La Rioja, Spain.
mario.arribas.garcia@gmail.com

Received: 2015-05-22 / Sent for peer review: 2015-07-30 / Accepted by peers: 2015-09-15 / Approved: 2015-11-04 To reference this article in APA style / Para citar este artículo en APA / Para citar este artigo Arribas, M. (2016). Analysing a whole CLIL school: Students' attitudes, motivation, and receptive vocabulary outcomes. Latin American Journal of Content and Language Integrated Learning, 9(2), 267-292. doi:10.5294/laclil.2016.9.2.2 


\title{
Analizando toda una escuela AICLE: actitudes, motivación y resultados en el vocabulario receptivo de los estudiantes
}

\begin{abstract}
Resumen
El enfoque AICLE sigue tomando fuerza en el contexto educativo europeo. Un claro ejemplo es España, en donde el número de escuelas que adoptan esta metodología ha crecido de forma exponencial en los últimos años. El presente estudio adopta una perspectiva dual en tanto analiza la motivación de los estudiantes frente al inglés y al enfoque AICLE, y a la vez muestra los resultados de los estudiantes en cuanto a su vocabulario receptivo. Todos los estudiantes $(n=403)$ matriculados en una escuela bilingüe secundaria completaron un cuestionario y desarrollaron dos exámenes de vocabulario receptivo (VLT Bandas $2 \mathrm{k}$ y $3 \mathrm{k}$ ). Los resultados del estudio dan cuenta de las opiniones de todos los estudiantes y correlacionan los resultados de vocabulario de los estudiantes de último año de educación obligatoria (16 años) con su motivación hacia el inglés. Una vez se analizaron el cuestionario y las versiones de la prueba VLT, se concluyó que el grupo AICLE tuvo resultados más altos en las pruebas de vocabulario receptivo debido a su alta motivación, aunque no se encontraron diferencias significativas estadísticamente (pruebas de Kolmogorov-Smirnov-Lilliefors, Shapiro-Wilk, y Mann-Whitney). Atribuimos esta falta de significación estadística a la implementación irregular del enfoque AICLE en la escuela y la corta experiencia de la escuela con esta metodología.
\end{abstract}

Palabras clave: AICLE; vocabulario receptivo; actitudes; motivación. 


\title{
Analisando toda uma escola AICLE/CLIL: atitudes, motivação e resultados no vocabulário receptivo dos estudantes
}

\begin{abstract}
Resumo
A abordagem da Aprendizagem Integrada de Conteúdos e de Língua (AICLE/CLIL) continua ganhando força no contexto educativo europeu. Um claro exemplo é a Espanha, onde o número de escolas que adotam essa metodologia tem crescido de forma exponencial nos últimos anos. Este estudo adota uma perspectiva dual, pois analisa a motivação dos estudantes ante o inglês e a abordagem AICLE/CLIL, ao mesmo tempo que mostra os resultados dos estudantes no que se refere ao seu vocabulário receptivo. Todos os estudantes $(n=403)$ matriculados numa escola bilíngue de ensino fundamental responderam a um questionário e desenvolveram dois exames de vocabulário receptivo (VLT Bandas 2k e 3k). Os resultados do estudo dão conta das opiniões de todos os estudantes e correlacionam os resultados de vocabulário dos estudantes do último ano de educação obrigatória (16 anos) com sua motivação para o inglês. Uma vez analisados questionário e versões do teste VLT, concluiu-se que o grupo AICLE/CLIL teve resultados mais altos nas provas de vocabulário receptivo devido à sua alta motivação, embora não tenham sido encontradas diferenças significativas estatisticamente (testes de Kolmogorov-Smirnov-Lilliefors, Shapiro-Wilk e Mann-Whitney). Atribuímos essa falta de significação estatística à implantação irregular da abordagem AICLE/CLIL na escola e à falta experiência desta com essa metodologia.
\end{abstract}

Palavras-chave: AICLE/CLIL; atitudes; motivação; vocabulário receptivo. 


\section{INTRODUCTION}

Nowadays one of the trendiest terms in the European educational scenarios is CLIL (content and language integrated learning) that refers to the use of a second or foreign language (FL) as a vehicle to learn the content of a school curricula subject. Yet CLIL is only a relatively new term, which accounts for an old educational method. Mehisto, Marsh, and Frigols (2008) remark how many centuries ago Latin was the language used for instructional purposes at universities. However, as these authors note, the use of Latin was not CLIL in its purest form, since little attention was paid to vernacular languages, meanwhile the will to integrate vernacular and national languages in the school curricula is regarded as one of the main innovations of CLIL in comparison to old methodological similar approaches.

This idea is not completely new either because, in Canadian and USA schools, a prototype of CLIL methodology was implemented by means of immersion programs as early as 1960, although under a different label: Content-based language teaching or Content-Based Instruction (CBI) (Mohan, 1986).

In the last decades CLIL has emerged with force due to its attractive tenets but also due to the international climate enjoyed by Europe at the present time. As to the former, most proponents of CLIL mention the following (Coyle, Hood, \& Marsh, 2010; Marsh \& Wolff, 2007; Mehisto, 2008; Mohan, 1986):

- Language is regarded as an instrument to learn the content of a subject in the school curricula.

- The focus is on content rather than on language and its grammatical rules.

- Language is learnt in a natural way in the classroom setting. Mohan (1986) says that "language ceases to be taught in isolation" and Coyle et al. (2010) add that "... it combines different concepts that have been treated as separate entities: CLIL is the point where language learning and subject learning converge".

- It relates learning and language learning to the real world as Maths, History or Music are real things for learners.

- It increases learners' exposure to the target language. 
- CLIL prepares students for living in a society which is becoming more and more internationalised, increasingly global and multilingual.

CLIL in Europe is characterised by a great diversity in its implementation. Experiences differ among regions within the same country but also among schools in a single town. According to Eurydice's report (2005), this situation is closely linked to the autonomy given to countries, regions, communities, and schools. However, the diversity of experiences has to do with the lack of regulation or official guidelines, and more particularly a) teachers' linguistic competence, b) teachers' training, c) language level to be achieved by learners, and d) distribution of CLIL hours. For instance, in France, Poland or Hungary prospective CLIL students are selected based on their performance on entrance exams both on the target language and on subject knowledge. In contrast, in Spain, Germany, Finland or Sweden, CLIL is normally opened to every single student. We see, thus, that there are many differences regarding how CLIL is put into practice.

The purpose of this paper is to look at how CLIL is implemented in a school in La Rioja in the secondary education setting and to look at 1) its effect on students' linguistic competence and 2) their motivation. We followed these procedures 1) analysing their scores on different vocabulary tests and 2) asking learners about their views on CLIL. To provide the context for our research, we deem necessary to give a concise account of the situation of CLIL in La Rioja.

To achieve this goal, we followed the most recent and up-to-date book on this issue: CLIL in Spain (Lasagabaster \& Ruiz de Zarobe, 2010). In addition, for our review of CLIL in La Rioja we will also fall back on Fernández Fontecha (2009, 2010). As stated by Fernández Fontecha (2010), La Rioja is a monolingual community where immigration and tourism have a huge importance due to the culture of wine, The Way of St. James, and San Millán de La Cogolla, i.e. the cradle of the first Spanish words. This author points out the existence of some initiatives designed to improve the teaching of foreign languages, such as the PILC Project (Proyectos de Innovación Lingüística en Centros, i.e. School Language Innovation Projects) which consists of two different possibilities of using English or French in the classroom. These two types are: Type A) where the foreign language is used for greetings, routines, and instructions, and Type B) where part of 
the curriculum is taught in the FL. This project has experienced a noticeable growth in presence and importance among schools: the number of schools involved has risen from 10 to 46 schools between 2003 and 2010.

Bilingual Sections, a different way of CLIL in schools in La Rioja, are also introduced and explained in Fernández Fontecha (2010) and, in this type of instruction, at least two subjects can be taught in a FL so long as the total number of hours taught in the foreign language does not surpass the $50 \%$ of the total hours of the curriculum.

So far we have briefly portrayed the situation of CLIL in La Rioja, and we can conclude that it is not consistent at all, as it occurs in Spain and Europe. Nevertheless, in spite of its diversity CLIL seems to be effective and to produce good results, although empirical research in this respect is still scarce and it usually focuses on one single aspect (Lasagabaster \& Ruiz de Zarobe, 2010) of CLIL, therefore results cannot be generalised. This paper attempts to describe how CLIL is implemented in a school in La Rioja by providing a wider and deeper picture focusing on students' attitudes and one aspect of their communicative competence. Before getting any deeper on the study, it is necessary to have a look at the literature about the topics of motivation, CLIL, and its relationship.

The following paragraphs are devoted to reviewing the literature on the following areas of research 1) studies on learners' beliefs and attitudes towards foreign languages, 2) studies on attitudes towards English language teaching/learning both in CLIL and in non-CLIL settings, and 3) empirical studies on the effect of CLIL.

Regarding studies that have addressed the issue of attitudes towards language learning, we find Delfin de Manzanilla (2007) who shows that university learners are both internally and externally motivated towards language, they are willing to communicate in the FL, and they also hold positive attitudes towards foreign language speakers.

Likewise university students have positive attitudes towards bilingualism (Mohideen Obeidat 2005). Research also points out that teachers are one of the main sources for motivation whether positive or negative. These results reported by Mohideen Obeidat (2005) are similarly found in González Ardeo (2003), because the latter concludes that Spanish and Basque bilinguals and Spanish or Basque monolinguals university stu- 
dents show positive attitudes towards English although they are reluctant to be taught in English.

Other studies (Liuolienè \& Metiūnienè, 2006), apart from reaffirming the importance of motivation in the learning process do reveal that students' wishes and needs to work independently rely highly on their motivation. These studies also indicate that the greater the motivation, the more autonomous students want to be in their learning process. In our opinion, this latter assertion can be related to one of the main assumptions advocated by CLIL: it fosters cognition and students' independent learning.

However, primary and secondary school students are not as motivated as elder learners regarding foreign languages (Karahan, 2007; Yassin et al., 2009). Research has shown that lower levels of motivation have to do with the minimum contact that these learners experience with the language outside the classroom context; they are not motivated to learn a language because they do not think it is useful for their everyday life. From our viewpoint, this difference in motivation between university students and younger learners may be related to their ages and the proximity to the job market. University students and elder learners may consider that learning a foreign language could motivate them extrinsically i.e. help them to get a better job or a higher salary.

Being aware of learners' attitudes towards foreign languages is of paramount importance for teachers and researchers, but being aware of learners' attitudes towards language teaching methodologies is at least as important. As we have seen, studies have proved that teachers are one of the main driving forces in motivation; and we should not forget that the main bond between teachers and learners is the classroom context, i.e. the methodology the teacher uses. In this regard, it seems evident that teaching methodologies have a clear influence on making language learning more or less appealing to learners.

Savignon and Wang (2003) and Verma (2008) conducted research to ascertain university students' motivation and attitudes towards language learning. Regarding methodology, common findings are observed in these studies: students prefer, and are more motivated, with a communicative approach rather than with grammar-focused lessons. 
Finally, these studies suggest again that teachers are the main motivator for learners. These results are in agreement with the ones attained by Lennartsson (2008) since the learners in this study also consider that teachers influence positively or negatively their attitudes towards language.

To complete our review, we need to have a look at studies that have combined these attitudinal factors with learning in a CLIL context. First of all, we will focus on students' perceptions. These studies on students' perceptions on CLIL are still scarce and in our review, we must fall back on Dalton-Puffer et al. (2009), where we see the views of Austrian university students involved in a CLIL programme. The results provided by these authors are of great value to us, as their findings do not seem to be fortuitous: 1660 former CLIL students answered a questionnaire and 20 students involved in CLIL completed a deeper interview. The main results obtained by Dalton-Puffer et al. are summarised as follows: a) CLIL encourages learners to talk and to think by themselves, b) they feel more motivated because the teacher is the language expert and the subject expert at the same time, c) students focus more on communication than on grammatical correctness, and d) CLIL lacks organization in the way it is implemented. Looking closely at these assertions we perceive that there is an agreement between students' views involved in a CLIL programme and the theoretical virtues attributed to CLIL.

We will now focus on students' attitudes towards CLIL. To this respect we will refer to two studies that have dealt with this issue in secondary school settings: Lasagabaster and Sierra (2009) and Yassin et al. (2009).

On the one hand, the main objective in Yassin et al. (2009) is to document the experiences of learners and to ascertain their views towards the teaching of Science through English in Malaysia. The study was conducted with "Year 4" students and the main findings were that NLEP (Non-Limited English Proficiency) learners, i.e. the CLIL-like group, have significantly more positive attitudes towards Science in English, greater parental support, and more experience using the English language than LEP (Limited English Proficiency) learners.

On the other hand, Lasagabaster and Sierra (2009) present the differences in language attitudes between CLIL students and non-CLIL students EFLlearners in secondary education in the BAC (Basque Autonomous Com- 
munity). They focus on how gender and social class have an influence on motivation towards foreign languages. This study reports that students who are involved in a CLIL programme show better attitudes towards English as well as towards other languages and find learning English easier than non-CLIL students.

Research on the effect of CLIL on learners' language competence is rather scarce when compared to the great number of studies on the implementation of CLIL or research on theories and principles of CLIL. Moreover, its systematisation is rather complex. The reason is that the studies on the effectiveness of CLIL differ the following aspects: the characteristics of the language learning contexts where CLIL was implemented, learners' age and mother tongue, learners' level in the target language, or the specific dimension of learners' competence that is investigated.

Comparisons among the studies, let alone outcomes' generalizations, are risky due to the huge variation among the existing studies but also because of the lack of information regarding the number of hours of CLIL received by the learners participating in the studies. This information is needed to compare outcomes but unfortunately, the number of hours of CLIL is not reported in most studies.

Most studies on the effectiveness on CLIL reveal, as theory and learners' views pointed out, that this approach entails better results for learners in most aspects of communicative competence and language skills as for instance: pronunciation, syntax, pragmatics, informal use of language, or reading comprehension, or writing (Admiraal et al., 2005; Agustín Llach \& Jiménez Catalán, 2007; Dalton-Puffer, 2007; Huttner \& Rieder-Bunemann, 2007; Llinares \& Whittaker, 2007; Jiménez Catalán \& Ruiz de Zarobe, 2009; Sylvén, 2010). In the following paragraphs we give a brief account of some of the studies that have focused on the effect of CLIL on dimensions of EFL learners' lexical competence.

CLIL has been proved to have a positive influence on lexical competence as shown in Jiménez Catalán et al. (2006) where they acknowledged that CLIL learners display higher lexical richness and sophistication in the vocabulary they use in compositions, as well as higher receptive vocabulary knowledge as measured by the 1000 and 2000 frequency bands of Vocabulary Levels Test (VLT). 
This study is not the only one to ascertain differences in favour of CLIL. Agustín Llach and Jiménez Catalán (2007) studied how the type of instruction affected lexical reiteration and productive vocabulary in written texts; results confirm again that students involved in a CLIL environment perform better than non-CLIL learners. However, they also remark that both CLIL and EFL learners resort to repetition rather than to synonyms or antonyms suggesting similar mechanisms of lexical cohesion by CLIL and EFL learners.

Ruiz de Zarobe and Jiménez Catalán (2009) edited a book that encompasses different studies that compare CLIL learners to non-CLIL learners with respect to different aspects of lexical competence such as receptive vocabulary, word association, and transfer between languages (Spanish-English) or use of inflected forms in English among others. In all cases but one CLIL students achieved better results than non-CLIL learners.

Apart from the mentioned competences, there are other extra linguistic aspects that have been studied i.e. the effects of extramural exposure to English on learners' vocabularies (Sylvén, 2006). Sylvén argues that CLIL students have more contact with English outside the school than non-CLIL students and this greater amount of exposure affects positively their self-assessment in English.

In a latter longitudinal study (Sylvén, 2010) differences in vocabulary size between a group of CLIL students and a group of EFL students are contrasted too. She reports that CLIL students performed better in all tests; however she highlights the importance of the exposure to English outside the class because some EFL students, those who affirmed having a wide contact with English outside the class-e.g. reading, T.V., Internetwere among the top scorers.

This fact leads us to the amount of exposure, a controversial issue in the field of language learning. Miralpeix (2007) studied the influence of exposure with regards to language learning. This study reveals that one group with greater exposure within the class -74 hours more- performed similarly to two other groups that had received less exposure to English. This fact leads us to think about the importance of methodology; since these findings seem to contradict studies where learners with more hours of exposure through CLIL have better results (Jiménez \& Ruiz de Zarobe, 2009). 
To close this review on studies on the effectiveness of CLIL and EFL learners' competences, we find mandatory to comment on that some researchers make clear that CLIL students are more motivated than non-CLIL students and it influences their achievement (Admiral el al., 2005; Sylvén, 2006; Huttner \& Rieder-Bunemann, 2007). These findings are key to our study because we will see the role that motivation plays in students' FL vocabulary results.

In the earlier paragraphs, we have attempted to review studies on learners' beliefs, attitudes and motivation towards CLIL. As we have seen that, although scarce, there is research on almost every variable involved in CLIL: teachers, learners, subjects, CLIL activities, and language learning contexts. However, as far as we know, there is no research that looks at the main participants in the CLIL experience within the same school, let alone through a whole educational stage.

Most studies give a partial view of CLIL as they focus on one single aspect. In our opinion, to advance in the understanding of CLIL, it is necessary to adopt a more comprehensive view that may provide a more detailed picture on the beliefs, attitudes, motivations and practices of the main participants in the CLIL experience. Therefore, in the study reported in this paper we set out to investigate learners' views on CLIL and learners' attitudes towards English and CLIL under the same scenario: the school where CLIL is being implemented. We do not set out to look at CLIL with preconceptions; rather we attempt to give a description of its reality by means of asking learners themselves. We believe that the adoption of a comprehensive approach in our study will provide us with invaluable data to identify strengths but also to detect possible weaknesses in the early stages of implementation of CLIL in the community of La Rioja.

\section{METHOD}

\section{Informants}

The study encompasses the school's whole population as regards secondary education (SE) in the school year 2009-2010. The population encompasses 403 students distributed among the four compulsory years of Spanish 
secondary education. Students' ages range from 12 to 16 . Table 1 shows the distribution of students by school grade and age range.

\section{Table 1. Distribution of students by school year and age range}

\begin{tabular}{|c|c|c|c|c|}
\hline Grade & 1st year & 2nd year & 3rd year & 4th year \\
\hline $\mathrm{N}$ & 104 & 99 & 108 & 92 \\
\hline Age range (years) & $12-13$ & $13-14$ & $14-15$ & $15-16$ \\
\hline
\end{tabular}

Regarding their mother tongue, most students are monolingual speakers of Spanish as L1, whereas a small group of students have Spanish as L2. Their mother tongues are: Romanian, Arabic, Bulgarian, Catalan, Chinese, Russian, Senegalese, and Urdu. ${ }^{1}$ The distribution of students' mother tongues is displayed in Table 2 .

Table 2. Distribution of students by mother tongue

\begin{tabular}{|c|c|}
\hline L1 Language & No. of Students \\
\hline Spanish & 392 \\
\hline Romanian & 4 \\
\hline Arabic & 1 \\
\hline Bulgarian & 1 \\
\hline Catalan & 1 \\
\hline Chinese & 1 \\
\hline Russian & 1 \\
\hline Senegalese & 1 \\
\hline Urdu & 1 \\
\hline
\end{tabular}

At this point it is necessary to make a further description of the characteristics of CLIL throughout the fourth grades in the school we investigate. The main difference between CLIL and non-CLIL groups lies in the fact that the former received additional hours of exposure to English language by means of CLIL methodology. However, the number of hours is far from

1 Spanish native speakers born in South or Central America are not included in this group; they belong to the Spanish natives group according to our classification. 
being equal, neither throughout the grades nor within each grade. Regarding CLIL, the situation of the school is rather complex and needs clarification, thus we tackle this issue in the following paragraphs. Figure 1 shows the distribution of students by type of instruction per year.

\section{Figure 1. Distribution of students by type of instruction per year}

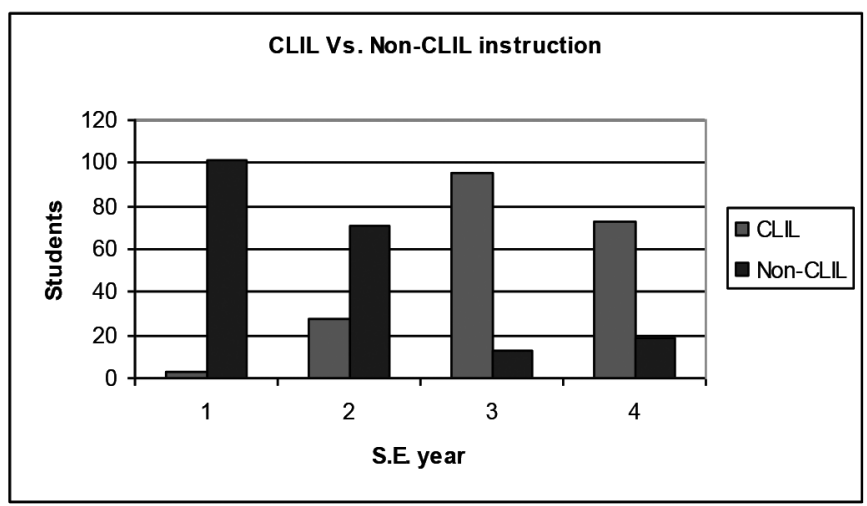

In the $1^{\text {st }}$ year, only 3 out of 105 students had had some previous CLIL experience throughout primary education. However, the number of hours of exposure to English could not be calculated; the reason is that these three students were new to the school and it was not a goal of this study to trace learners' previous CLIL experience in other schools but to focus on CLIL in one specific school.

In the $2^{\text {nd }}$ year, 28 out of 99 students had studied at least one subject through CLIL. However, the total number of hours could not be calculated either because the teacher in charge of the CLIL subject had left the school or because the students studied the CLIL subjects at a different school.

In the $3^{\text {rd }}$ year, the clear majority of students (96 out 108) had had some CLIL experience. The total number of CLIL hours per student ranges from 10 to 30 depending on the subjects studied through English. Figure 2 shows the number of CLIL hours that students received.

In the $4^{\text {th }}$ year, a high percentage of students had had CLIL experience: 75 out of 94. In this case, students had been taught from one to three subjects in English. The total number of CLIL hours ranges from 10 to 90 depending on the different subjects studied by the informants all along the 
four years of secondary education. Figure 3 shows the distribution of $4^{\text {th }}$ year students by the number of hours of CLIL instructions they received.

\section{Figure 2. Distribution of 3 rd year students by the amount of CLIL hours received}

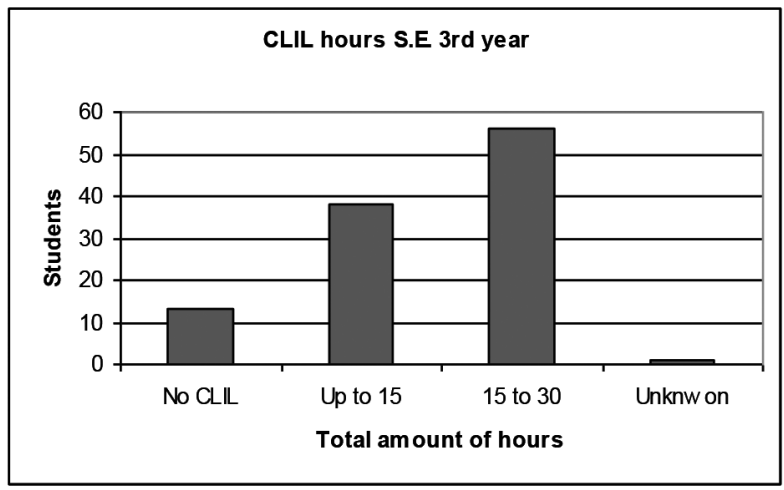

Figure 3. Distribution of 4 th year students by the amount of CLIL hours received

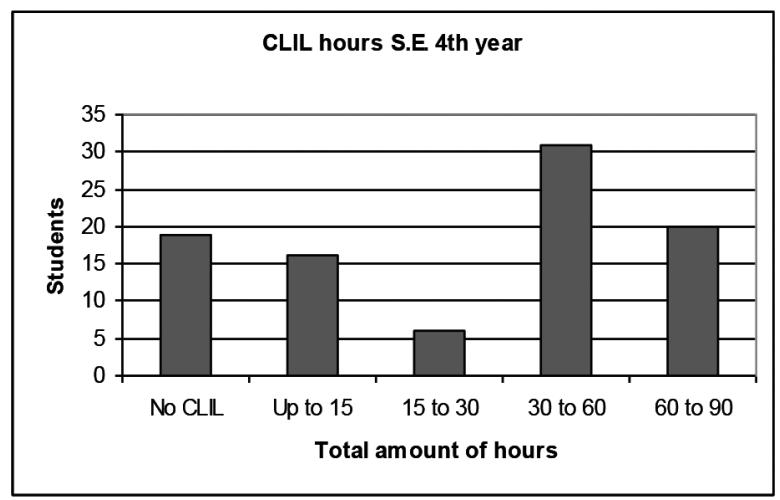

\section{Data collection instruments}

Students were asked to fill in a questionnaire designed ad hoc of the task, which was based on the same questionnaire used by the GLAUR group (Grupo de Lingüistica Aplicada de la Universidad de La Rioja - Applied Linguistics Group of the University of La Rioja). Some questions were added asking information about the students' CLIL experience and their perceptions and attitudes on it. 


\section{Procedures}

Once the data gathering was completed, we proceeded to type the questionnaires' results and finally, after having typed the responses to the questionnaire we proceeded to the quantitative analysis of the data, which was completed using different statistic tests (including here Kolmogorov-Smirnov-Lilliefors, Shapiro-Wilk, and Mann-Whitney among others tests) where needed by means of SPSS. ${ }^{2}$

\section{RESULTS}

In this section, we attempt to answer the research questions posed earlier by providing data elicited from students and teachers belonging to a CLIL school. In the first place, we provide the data obtained from students on their views on CLIL and their attitudes towards English.

\section{Students' views on CLIL}

Regarding our first research question the answer is negative since according to more than $80 \%$ of the students, CLIL is not considered as a useful experience. Figure 4 reveals that most of the students who had received CLIL instruction report that CLIL was either of 'very little help' or 'little help'. None of the students considered CLIL as 'very helpful'. Figure 4 shows the distribution of responses given by students regarding their views on CLIL.

Regarding our second research question, 'What skills have students improved most by means of CLIL?' two tendencies clearly emerge in the data shown in Figure 5. In the first place, a great number of students reported 'listening' and 'speaking' as the most positively influenced skills.

Secondly, we see that $3^{\text {rd }}$ year followed by $4^{\text {th }}$ year are the courses that concentrate the highest number of students who report CLIL to have been of help in the improvement of their linguistic skills (mainly listening). Contrary to what might have been expected, a noticeable percentage of students felt that CLIL had not boosted any of their skills.

2 We would like to acknowledge Montserrat San Martín, lecturer at the Mathematics and Computing Department of the University of La Rioja, for her invaluable help in test selection and statistical data analysis. 


\section{Figure 4. Distribution of responses given by students regarding their views on CLIL}

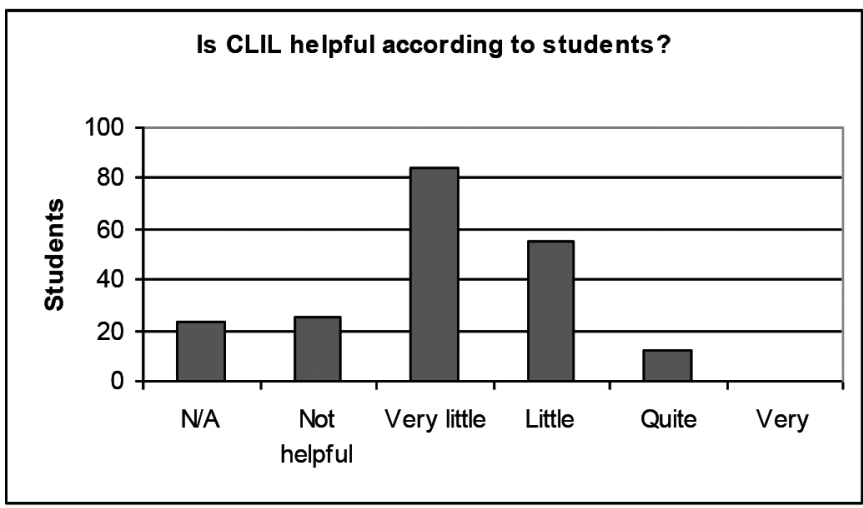

Also, as we can observe in Figure 5, vocabulary is included together with the four skills. The reason for its inclusion here is that all the students who believed that CLIL had helped them in the improvement of the four language skills also referred to the positive effect of CLIL on the development of their lexicons. Figure 5 shows the distribution of skills improved in each course.

Figure 5. Distribution of skills improved per course

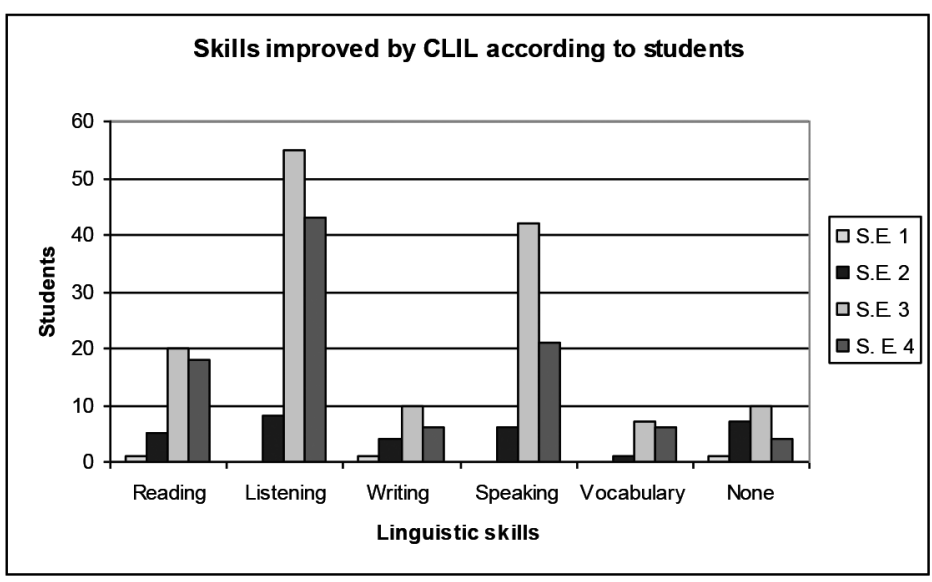

\section{Students' attitudes towards English}

We now turn our attention towards students' attitudes towards English (RO3), including here the two groups of students: CLIL and non-CLIL. To 
this purpose, both groups were asked to rate English according to an attitudinal scale made up of positive and negative. The minimum score is 1 and the maximum 7. The means show that CLIL students and non CLIL students hold very similar attitudes towards English language, although the means are slightly higher for the CLIL group throughout the four years. A close look at Table 3 reveals that the highest scores, therefore the most motivated students, were obtained by CLIL students in the last year of Spanish Secondary Education: $4^{\text {th }}$ ESO.

\section{Table 3. CLIL and non-CLIL students' attitudes towards English}

\begin{tabular}{|c|c|c|c|c|}
\hline Year & CLIL & $\mathbf{N}$ & Mean & S.D. \\
\hline \multirow{2}{*}{1 st year } & No & 101 & 5.5000 & 0.88829 \\
\cline { 2 - 5 } & Yes & 3 & 5.6250 & 0.78062 \\
\hline \multirow{2}{*}{ 2nd year } & No & 69 & 5.5236 & 0.94136 \\
\cline { 2 - 5 } & Yes & 28 & 5.5625 & 0.69264 \\
\hline \multirow{2}{*}{ 3rd year } & No & 13 & 5.2692 & 1.47624 \\
\cline { 2 - 5 } & Yes & 95 & 5.6018 & 1.03188 \\
\hline \multirow{2}{*}{4 th year } & No & 19 & 5.5977 & 0.58097 \\
\cline { 2 - 5 } & Yes & 73 & 5.7072 & 0.66836 \\
\hline
\end{tabular}

Although CLIL students score higher in their attitude towards English all through the four years, these differences were not statistically significant, as the results of Mann-Whitney $U$ test applied to the means gave us the following values ${ }^{3}$ as regards $1^{\text {st }}$ year $(U=137 ; z=0.778), 2^{\text {nd }}$ year $(\mathrm{U}=917.5 ; \mathrm{z}=0.699)$, and $3^{\text {rd }}$ year $(\mathrm{U}=556 ; \mathrm{z}=0.561)$.

Regarding $4^{\text {th }}$ year, the t-test ${ }^{4}$ performed showed non-significant differences either between CLIL and non-CLIL students. Results show a high value $(t=0.516)$ and we cannot affirm that these are significant because the $\mathrm{p}$-value should be less than $0.05(\mathrm{p}<0.05)$.

3 The Kolmogorov-Smirnov-Lilliefors Test run for normality testing showed the sample did not have a normal distribution $(p<0.05)$.

4 The Kolmogorov Smirnov-Lilliefors Test showed that the sample had a normal distribution ( $p>0.05$ ); thus as the assumption of normality was met, a parametric test was used to compare the two groups. 


\section{Students' vocabulary outcomes}

In this section we present the results obtained by our informants in the receptive VLT in its 2000 and 3000 words band version. It must be said that due to space limitations here we present solely the results corresponding to $4^{\text {th }}$ year of ESO. The reason for focusing exclusively on this course rather than the other three is that $4^{\text {th }}$ ESO stands for the final stage of Spanish secondary education. Furthermore, we will also present the results obtained from analysing the relationship between attitudes towards English, presented above, and students' achievement measured by means of VLT 2000 and VLT 3000.

As expected, both groups obtained higher scores in the VLT 2k rather than in the VLT $3 \mathrm{k}$ and differences between CLILs and non-CLILs are also greater in the former test. Figure 6 shows the $4^{\text {th }}$ year CLIL and non CLIL students' scores in VLT $2 \mathrm{k}$ and $3 \mathrm{k}$.

\section{Figure 6. 4th year CLIL and non CLIL students' scores in VLT 2k and $3 k$}

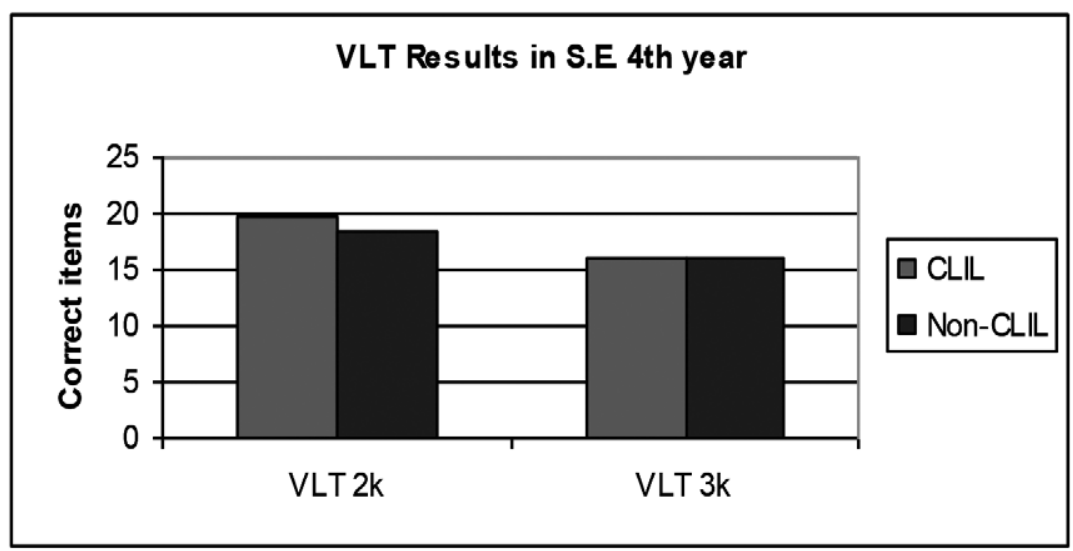

Although we find differences in favour of CLIL students, these were found not to be significant after analysing them statistically. As the results of Mann-Whitney $U$ test applied to the means gave us the following values as regards VLT200 $(U=603.5 ; \mathrm{z}=0.384)$, and VLT300 $(\mathrm{U}=690$; $\mathrm{z}=0.973) .5$ The Kolmogorov-Smirnov for contrasting two samples was also

5 The Kolmogorov-Smirnov-Lilliefors Test run for normality testing showed the sample did not have a normal distribution $(\mathrm{p}<0.05)$. 
applied to the data to search for significance, again non-significant differences were found between CLIL and non-CLIL students concerning their results on VLT2000 due to the high values $(t=0.646)$ and VLT3000 $(t=0.927)$.

\section{Relation between students' attitudes and vocabulary outcomes}

We present here evidence for the relationship between students' attitudes towards English language and vocabulary outcomes as measured by VLT2000 and VLT300. In this regard, there is a positive correlation (Spearman test) between attitudes and scoring in each VLT frequency band, and this correlation applies to all students, that is, those who had contact with CLIL and those who did not. In other words, the more motivated the students are about English, the better their vocabulary.

The results tell us that there is a significant increasing relationship between students' attitudes towards English and their vocabulary performance. The values obtained were as follows: $\mathrm{r}=0.420, p<0.000$ for VLT2000, and $\mathrm{r}=0.349, p<0.001$ for VLT3000. The significant correlation suggests that the better the attitudes towards English the better the performance on the two bands analysed from VLT test. It does not matter if the students have received any kind of CLIL instruction or not.

The p-values (0.000 in VLT 2000 and 0.001 in VLT 3000) are less than 0.05 , which indicates that the relation between attitudes and outcomes is significantly different. Furthermore the r-values higher than 0.00 (0.420 for VLT 2000 and 0.349 for VLT 3000) indicate that this is an increasing relation: the higher the score in motivation, the better the results in VLT 2000 and VLT 3000.

\section{DISCUSSION}

The results of our study provide us with different kinds of evidence on varied issues like students' motivation towards English or the perceptions that they have on CLIL. We try to provide a valid interpretation to these results in the following lines.

Concerning students' motivation, our results suggest that although EFL and CLIL students get similar scores, students receiving some kind of CLIL instruction show better attitudes towards English as compared to 
those students that are not involved in content teaching. Nevertheless, our findings are not limited to this fact because, as it was explained in the previous section, there is a strong link between motivation and achievement since the more motivated students are also the ones that obtained the highest scores regardless of their instruction.

Our results seem to match those attained by Pérez (2006) and İnal, Evin, and Saracaloğlu (2007) where authors stress the importance of the positive relationship that binds motivation to achievement. However, there is one main difference if we are to compare their studies with ours: the age of informants. Our informants are in the last year of the secondary education, i.e. 15 to 16 years, whereas their informants were already university students, so they were at least 18 years old by the time their studies had been carried out.

As we have seen, we can see a difference in age but also a similarity in the motivation-achievement relationship. This leads us to think that the influence that motivation has on achievement might remain, at least, stable throughout different educational stages, as we have seen.

Regarding motivation, we mean to fulfil and answer at the same time one of our research questions: Does CLIL affect students' motivation?

Other studies make clear that students from primary levels (Karahan, 2007; Yassin et al., 2009), through to secondary levels (Lasagabaster \& Sierra, 2009) and university students (González Ardeo, 2003; Savignon \& Wang, 2003; Mohideen Obeidat, 2005; Delfín de Manzanilla, 2007; Lennartsson, 2008; Verma, 2008; Dalton-Puffer et al., 2009) have positive attitudes towards other languages different to their L1 due to different and varied internal and external factors, and our results appear to be in line with them, because our informants from the 4 courses presented high scores, on average, when they were asked to evaluate English.

Similar to our study is the one conducted by Lasagabaster and Sierra (2009) because their informants are the same age as ours and both of us measured students' attitudes towards English by means of the same item of the given questionnaire therefore we can establish an interesting comparison with their study.

We compared our informants' attitudes with the mentioned study and we realized that in Lasagabaster and Sierra, CLIL groups had signifi- 
cantly better attitudes than EFL groups. This might be possibly due to a greater amount of exposure to English in favour of their informants. We do not think that the socioeconomic context of the informants in each of the studies can make a big difference because the cities where both questionnaires were administered on areas in the North of Spain and not far from each other.

Nevertheless, it is very important from our point of view noting that there is a great difference between the cultural contexts: English is L2 for our informants whereas English is L3 for Lasagabaster and Sierra's informants. It implies that their informants live in a multilingual community and they might have developed more positive attitudes towards languages than our informants.

In addition, although the number of hours of exposure to English is not made clear in Lasagabaster and Sierra, we tend to think that their informants might have received a greater exposure. According to previous studies (Sylvén, 2006; 2010), a greater amount of exposure to the foreign language has a positive influence on the learner's attitude towards it.

Nevertheless, it is important not to forget that CLIL is still in a preliminary stage in La Rioja, let alone the school of our study. Therefore we think that, for the moment, a greater emphasis should be put on the amount of hours while CLIL undergoes a global process of standardization. We have noticed that the implementation of this methodology is somewhat irregular in the school under study and it might have had a negative effect on students' attitudes.

In the process of developing the study we also interviewed 2 CLIL teachers and 2 EFL teachers about the situation of the school regarding bilingualism, but we decided not to include their opinions in the frame of this study. However, their opinions might help to understand why students' outcomes in vocabulary are not as high as it could be expected from the circumstances.

On the one hand, CLIL teachers were highly motivated about the use of this methodology although they affirmed that they did not have as much time as they would like to devote to prepare classes and materials, which, by the way, according to them were also very limited in number and quality for their subjects, namely Religion and Mathematics. From 
the conversations with them, we could infer that although the intention and motivation to perform a better CLIL were high, they acknowledged the actual implementation did not meet their expectations and more work needed to be done.

On the other hand, EFL teachers provided a more pessimistic approach towards CLIL and thought that it could be improved overall because students were not showing noticeable improvements in their learning.

These perspectives provide us with a different point of view about the school and let us see that CLIL implementation is somewhat irregular, what goes in line with the global European situation where CLIL does not follow a set of standardized processes. It might justify students' motivation, perspectives, and outcomes.

\section{CONCLUSION}

By means of questionnaires and tests we have tried to provide a bird's-eye view on a whole single CLIL secondary Spanish school, something that had not been done previously as far as we are concerned. We have done that by presenting students' perceptions on CLIL and their results on vocabulary, and to a lesser extent, teachers' opinions.

We have tried to fulfil three main objectives and to do that, we proposed some research questions, which we think, have been answered. Results have proved on one hand that CLIL seems to have a positive effect on students, as it was expected. However these interpretations should be taken with extreme care because statistical tests affirmed that the positive differences in favour of CLIL students were not significant. We attribute the lack of significance to the irregular implementation of CLIL in the school because a poor implementation of CLIL might affect negatively learners' opinions and motivation.

On the other hand, results showed that although different teachers have different approaches to CLIL, teachers and students' perceptions match up when it comes to the linguistic skills that students are supposed to have improved after having been involved in a CLIL context. Even though we did not run any tests to find the relevance between learners' opinions and their vocabulary outcomes, we tend to think that these results could 
have been higher if learners perceived CLIL as a more organized and standardized method.

These interpretations should also be cautiously considered due to the relatively pioneer character of the work and, also due to this fact: there is room for further studies which may aim at investigating and helping to improve CLIL.

In order to close the article we must make reference to the implications that this study might have for teachers and researchers. In the first place, from our point of view, it is obvious that Spanish students need a higher competence in English if CLIL is meant to be successful, because both CLIL and EFL teachers confirmed that they considered that learners had a low competence and it hindered them from using English as the vehicular language all year long.

Besides we have also learnt that attitudes towards languages have a significantly positive influence on students' achievement; therefore, teachers should really make an effort to enhance their pupils' motivation and attitudes, in this case towards English, because different studies place teachers as one of the main driving forces in language learning.

\section{REFERENCES}

Admiraal, W. et al. (2006). Evaluation of bilingual secondary education in the Netherlands: Students' language proficiency in English. Educational Research and Evaluation, 12(1), 75-93.

Agustín Llach, M. P. (2006). Lexical errors in young EFL learners: How do they relate to proficiency measures? Interlingüistica, 17, 63-73.

Agustín Llach, M. P. (2007). Lexical errors as writing quality predictors. Studia Linguistica 61(1), p1-19.

Agustín Llach, M. P. \& Jiménez Catalán, R. M. (2007). Lexical reiteration in EFL young learners' essays: Does it relate to the type of instruction? International Journal of English Studies, 7, 85-103.

Coyle, D., Hood, P. \& Marsh, D. (2010). CLIL: Content and language integrated learning. Cambridge, UK: Cambridge University Press. 
Dalton-Puffer, C., Hüttner, J., Schindelegger, V., \& Smit, U. (2009). Technologygeeks speak out: What students think about vocational CLIL. International CLIL Research Journal, 1(2), 18-25.

Delfín de Manzanilla, B. (2007). Attitudes towards English in higher education students. REDHECS, 2, 1-35.

Eurydice. (2006). Aprendizaje integrado de contenidos y lenguas (AICLE) en el contexto escolar europeo. Madrid, Spain: Omagraf.

Fernández Fontecha, A. (2009). Spanish CLIL: Research and official actions. In Y. Ruiz de Zarobe \& R. M. Jiménez Catalán (Eds.). Content and language integrated learning: Evidence from research in Europe (pp. 3-22). Clevedon, UK: Multilingual Matters.

González Ardeo, J. M. (2003). Attitude towards English and ESP acquisition as an L2 or L3 at university. Ibérica, 6, 109-133.

Huttner, J. \& Rieder-Bunemann, A. (2007). The effect of CLIL instruction on children's narrative competence. VIEWZ, 16, 20-27.

İnal, S., Evin, İ., \& Saracaloğlu, A. S. (2005, October). The relation between students' attitude toward foreign language and foreign language achievement. Paper presented at the First International Conference, Dokuz Eylül University, Buca Faculty of Education, 1-3 October 2005, İmir. Retrieved from http://dergiler.ankara.edu.tr/ dergiler/27/754/9618.pdf

Jiménez Catalán, R. \& Ojeda Alba, J. (2009). Disponibilidad léxica en inglés como lengua extranjera en dos tipos de instrucción. Lenguaje y Textos, 30, 167-176.

Jiménez Catalán, R.M., Ruiz de Zarobe, Y. \& Cenoz, J. (2006). Vocabulary profiles of English Foreign Language learners in English as a subject and as a vehicular language. Vienna English Working Papers, 15, 23-27.

Karahan, F. (2007). Language attitudes of Turkish students towards the English language and its use in Turkish context. Journal of Arts and Sciences, 7, 73-87.

Lasagabaster, D. \& Ruiz de Zarobe, Y., eds. (2010) CLIL in Spain:Implementation, results and teacher training. Newcastle, UK: Cambridge Scholars Publishing. 
Lasagabaster, D. \& Sierra,J.M. (2009).Language attitudes in CLIL and traditional EFL classes. International CLIL Research Journal, 1, 4-17.

Lennartsson, F. (2008). Students' motivation and attitudes towards learning a second language: British and Swedish students' points of view. Retrieved from http://www.diva-portal.org/smash/get/ diva2:206523/fulltexto1.pdf

Liuolienè, A. \& Metiūnienè, R. (2006). Second language learning motivation. Santalka: Filosofija, Komunikacija, 2, 93-98.

Llinares García, A. \& Whittaker, R. (2007). Talking and writing in the social sciences in a foreign language: A linguistic analysis of secondary school learners of geography and history. In F. Lorenzo, S. Casal, V. Alba \& P. Moore (Eds.), Models and practice in CLIL (pp. 83-94). Logroño, Spain: Revista Española de Lingüística Aplicada (RESLA).

Marsh, D. \& Wolff, D. (Eds.). (2007). Diverse contexts, converging goals: CLIL in Europe. Frankfurt, Germany: Lang.

Mehisto, P., Marsh, D. \& Frigols-Martín, M. J. (2008). Uncovering CLIL: Content and language integrated learning in bilingual and multilingual education. Oxford, UK: Macmillan Education.

Miralpeix, I. (2007). Lexical knowledge in instructed language learning: The effects of age and exposure. International Journal of English Studies, 7, 61-83.

Mohan, B. A. (1986). Language and content. Reading, MA: Addison-Wesley. Mohideen Obeidat, M. (2005). Attitudes and motivation in second language learning. Journal of Faculty of Education UAEU, 22, 1-17.

Pérez, C. J. (2006). Motivación interna y rendimiento de los estudiantes de inglés de la ULA Táchira. Acción Pedagógica, 15, 64-73

Ruiz de Zarobe, Y. \& Jiménez Catalán, R. M. (Eds.) (2009). Content and language integrated learning: Evidence from research in Europe. Bristol, UK: Multilingual Matters.

Savignon, S. \& Wang, C. (2003). Communicative language teaching in EFL Contexts: Learners' attitudes and perceptions. International Review of Applied Linguistics in Language Teaching, 41, 223-249.

Sylvén, L.K. (2006). How is extramural exposure to English among Swedish school students used in the CLIL classroom? VIEWZ, 15(3), 47-53. 
Sylvén, L. K. (2010). Teaching in English or English teaching? On the effects of content and language integrated learning on Swedish learners' incidental vocabulary acquisition. Göteborg, Sweden: Göteborgs Universitet.

Verma, M. H. (2008, June). Learner's attitude and its impact on language learning. Paper presented at Language Issues in English-medium Universities: A Global Concern, Rayson Huang Theatre, University of Hong Kong, China, 18-20 June 2008. Retrieved from http:// www.hku.hk/clear/conferenceo8/doc/handouts/VERMA\%20 Meenakshi\%2OH_handout.pdf

Yassin, S. M., Marsh, D., Eng Tek, O. \& Ying Ying, L. (2009). Learners' perceptions towards the teaching of science through English in Malaysia: A quantitative analysis. International CLIL Research Journal, 1(2), 54-69. 